\title{
The Influence of Assignment of Lecturers at School (ALS) Program on Students Learning Motivation in Tarakan City
}

\author{
Emma Juwita Magdalena Sirait ${ }^{1}$, Sitti Hardiyanti Arhas², Suprianto \\ ${ }^{1}$ Borneo Tarakan University \\ ${ }^{2}$ Universitas Negeri Makassar \\ Email: emmasirait@gmail.com, a.arhas.03@gmail.com, antosaid.m@gmail.com
}

(Received: March-2019; revised: May -2019; published: June -2019)

\begin{abstract}
Borneo Tarakan University which is the only State University that prepares educators in the North Kalimantan region to take part to help realize the School Lecturers Assignment Program (LAS) which is a program from the Ministry of Research, Technology and Higher Education which aims to facilitate lecturers to directly becoming "teachers" in the School to improve the quality of prospective teacher students. The aims of study of: to know the description of Assignment of Lecturers at School (ALS) program, to know the description of student learning motivation, and to know the influence of the Assignment of Lecturers at School (ALS) program on student motivation in Tarakan City. The techniques used in collecting data are observation, questionnaires, and observation. While data processing and data analysis is done by descriptive analysis and inferential statistical analysis. The results of the study show that the description of the implementation of lecturer assignments in schools in a good category, while students learning motivation in the high category, and there a positive and significant influence between the implementation Assignment of Lecturers at School (ALS) program in learning motivation in Tarakan, which was $52.5 \%$
\end{abstract}

Keywords: ALS; Motivation;Lecturers; Students.

\section{INTRODUCTION}

Education is the frontline for building competitive young people in an era of globalization that has an impact on schools, teachers, and teacher education to help policy makers and practitioners continue to innovate (Direktorat Pembelajaran, 2018; Wang, Lin, Spalding, Odell, \& Klecka, 2011). Therefore, continuous education must be built and developed to produce a superior generation through the learning process, because teaching is a complex matter. An educator especially teachers are required to master various perspectives and learning strategies and must implement them flexibly. Good teachers have good strategies to motivate students to want to learn (Koca \& Ph, 2016; Lumsden, Learn, \& Digest, 1994; Thoonen, Sleegers, Peetsma, $\&$ Oort, 2011). Motivation contains a social component, one of which is social relations with the teacher by which a teacher is required to be professional (Borko, 2004; Darling-Hammond, Hyler, \& \& Gardner, 2017; Timperley, Wilson, Barrar, \& Fung, 2008). Borneo Tarakan University which is the only State University that prepares teaching staff especially in North Kalimantan to take part to help realize the Assignmentof Lecturers at School (ALS) Program which is a program of the Ministry of Research, Technology and Higher Education which aims to facilitate lecturers to live directly become "teachers" in schools that aim to improve the quality of prospective teacher students. One of the achievements expected in the Assignmentof 


\author{
80 Jurnal Administrare: Jurnal Pemikiran Ilmiah dan Pendidikan Administrasi Perkantoran \\ Volume 6 No. 1 January-June 2019. Pages 79-88
}

Lecturers at School (ALS) is the implementation of assistance in achieving the quality of learning through ALS with indicators of success, namely the creation of an increasingly better learning climate, the creation of increasingly quality learning devices, and increased learning achievement of students. Without sufficient motivation, even individuals with the most remarkable abilities cannot accomplish long-term goals (Emmer \& Stough, 2001; Peacock, 2003; Seifert, 2004).

The recapitulation of a number of studies conducted by lecturers and students of the Faculty of Teacher Training and Education of Borneo Tarakan University (FKIP-UBT) shows that approximately $70 \%$ of elementary and junior high school teachers in North Kalimantan Province, especially Tarakan, still conduct classroom learning using only lecture methods even though in some schools the 2013 curriculum has used the scientific approach. This is because the interpretation and application of the 2013 curriculum has not been fully maximized. This also shows the results of the Tarakan Middle School National Examination in 2017 where only 4 of the 23 schools achieved an average score of 60 (sixty), namely; Tunas Kasih Tarakan Christian Middle School, Tarakan Indo-Chinese Plus Middle School, Tarakan Middle School and IT Ulul Albab Tarakan Middle School. Assignmentof Lecturers at School (ALS)Program essentially aims to maximize the role of lecturers in improving the quality of learning in schools. In addition, this program is also beneficial for teachers, where they can find out and be able to apply varied learning models that are in accordance with the 2013 curriculum. The assignment of Lecturers in Schools also provides experience for the lecturers concerned about the learning process that occurs at school. The schools that were made partners by FKIP-UBT in the Assignmentof Lecturers at School (ALS) Program, namely Public Elementary School 020 Tarakan, Public Elementary School 037 Tarakan, Tarakan 1 Junior High School, and Hangtuah Tarakan High School. The aims of study of: to know the description of Assignment of Lecturers at School (ALS) program, to know the description of student learning motivation, and to know the influence of the Assignment of Lecturers at School (ALS) program on student motivation in Tarakan City.

\title{
METHOD
}

This research is a kind of associative quantitative research. The population in this study were all Hangtuah Tarakan high school students who were the focus of the implementation of the lecturer assignment program at the school. The population in this study were 66 respondents who came from class X Mia 1 and Class X Mia 3, because respondents were less than 100 people, by which the population was sampled. The instrument in this study was a research questionnaire and observation. Analysis of the data used is descriptive and inferential analysis techniques. The descriptive statistical analysis technique is used to describe the condition or characteristics of each research variable singly by using mean and standard deviation analysis. Inferential statistical analysis techniques for data normality tests using SPSS 24 statistics as well as simple linear regression analysis to determine the effect of Assignmentof Lecturers at School (ALS) Program on Student Learning Motivation at Hangtuah Tarakan High School. 


\section{RESULT AND DISCUSSION}

\section{Description of the Assignment of Lecturers in Schools (ALS)}

To obtain an overview of the implementation of ALS, the variables are made frequency tables and categories where both variables are measured using very good, good, good enough, not good enough, and very bad categories, while for students learning motivation using very high, high, high enough, not high enough, and not high.Based on the questionnaire given to 66 students who became the study sample, the average score for ALS Implementation was 59,378 with a standard deviation of 5.50 which was in the good category. To find out the description of ALS Implementation, can be seen in the following table:

\section{Table 1.}

Description of ALS Implementation

\begin{tabular}{rcl}
\hline Interval & Frequency & Category \\
\hline $63-75$ & 17 & Very Good \\
$51-62$ & 45 & Good \\
$39-50$ & 4 & Good Enough \\
$27-38$ & 0 & Not Good Enough \\
$15-26$ & 0 & Bad \\
\hline Total & 66 & \\
\hline
\end{tabular}

Source: Results of 2018 Research Analysis

From the table it can be seen that the implementation of ALS in Hangtuah City Tarakan High School, if viewed from the average (mean) is in good category with a frequency of 45 . This illustrates that the implementation of ALS at Hangtuah City Tarakan High School, both in terms of: creation an improved learning climate, resulting in increasingly quality learning devices, and increased learning achievement of students. In more detail, the results of research based on indicators are shown in Picture 1:

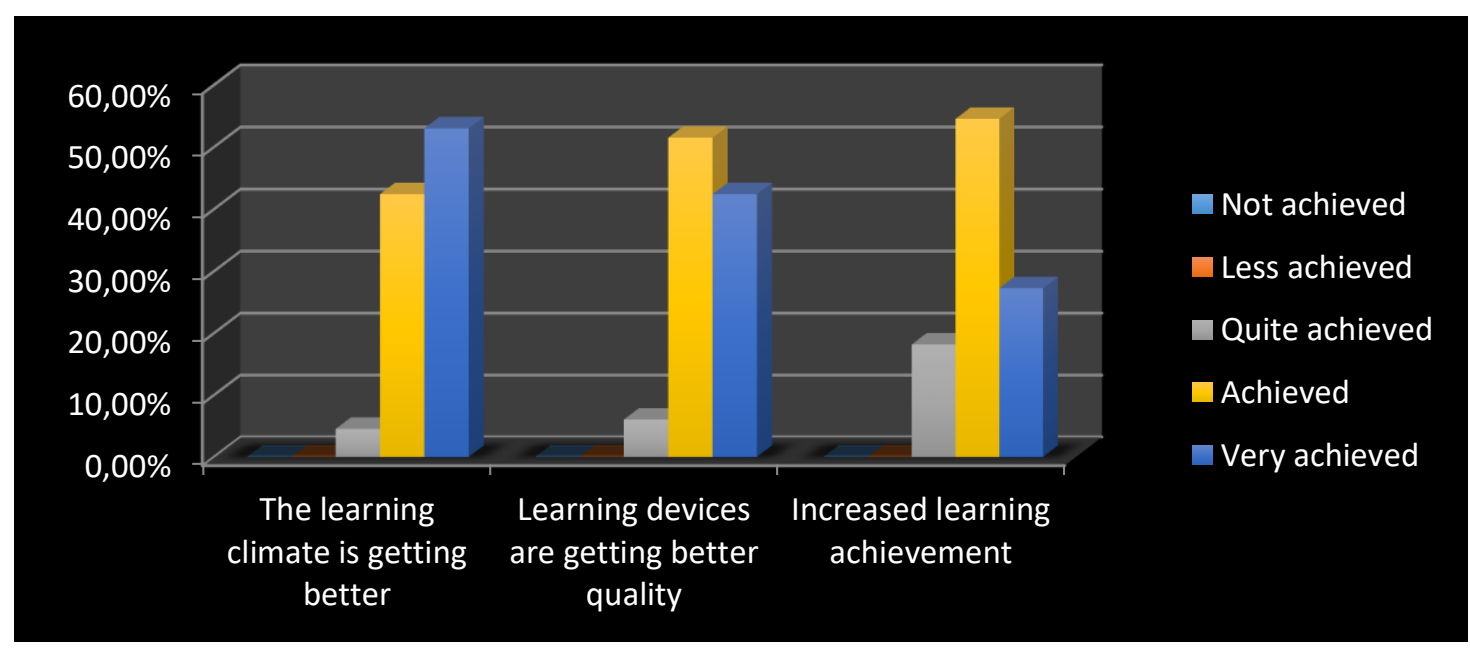

Picture 1. An Overview of ALS Implementation Based on Indicators 


\section{2 | Jurnal Administrare: Jurnal Pemikiran Ilmiah dan Pendidikan Administrasi Perkantoran Volume 6 No. 1 January-June 2019. Pages 79-88}

From the diagram it can be concluded that, the achievement of ALS, namely the implementation of assistance in achieving the quality of learning through ALS with the success indicators of the better learning climate is very achievable, increasingly quality learning devices can be achieved, and increasing student achievement can also be achieved.

From the results of data processing, it was found that the learning climate indicators were getting better, $53.03 \%$ of respondents said they were very achieved, $42.42 \%$ of respondents said they were achieved, and $4.55 \%$ of respondents said that they were quite achieved. The goal is that learning devices become more competent, $42.42 \%$ of respondents said that it was very achieved, $51.52 \%$ of respondents said that it was achieved, and $6.06 \%$ of respondents said that it was quite achieved. Whereas for the purpose of increasing learning achievement, $27.27 \%$ of respondents said it was very achievaed, $54.55 \%$ of respondents said it was achieved, and $18.18 \%$ of respondents said that it was quite achieved.

\section{Description of student learning motivation}

Based on the questionnaire given to 66 students who became the study sample, the average score for Student Learning Motivation was 39,287 with a standard deviation of 4,7483. To find out an overview of student learning motivation, can be seen in Table 2:

Table 2.

Description of Student Learning Motivation

\begin{tabular}{lll}
\hline Interval & Frequency & Category \\
\hline $42-50$ & 21 & Very High \\
$34-41$ & 34 & High \\
$26-33$ & 11 & High Enough \\
$18-25$ & 0 & Not High Enough \\
$10-17$ & 0 & Not High \\
\hline Total & 66 & \\
\hline
\end{tabular}

Source: Results of 2018 Research Analysis

From the table, it can be seen that students 'motivation in Hangtuah City Tarakan High School, if viewed from the average (mean) is in the high category with a frequency of 34 . This illustrates that students' learning motivation at Hangtuah High School in Tarakan city is high in terms of : doing task, solve the problem, learn to be independent, glad to work independently, challenging task, defend opinions, not easily giveup. The results of the research based on the indicators are shown in Picture 2: 


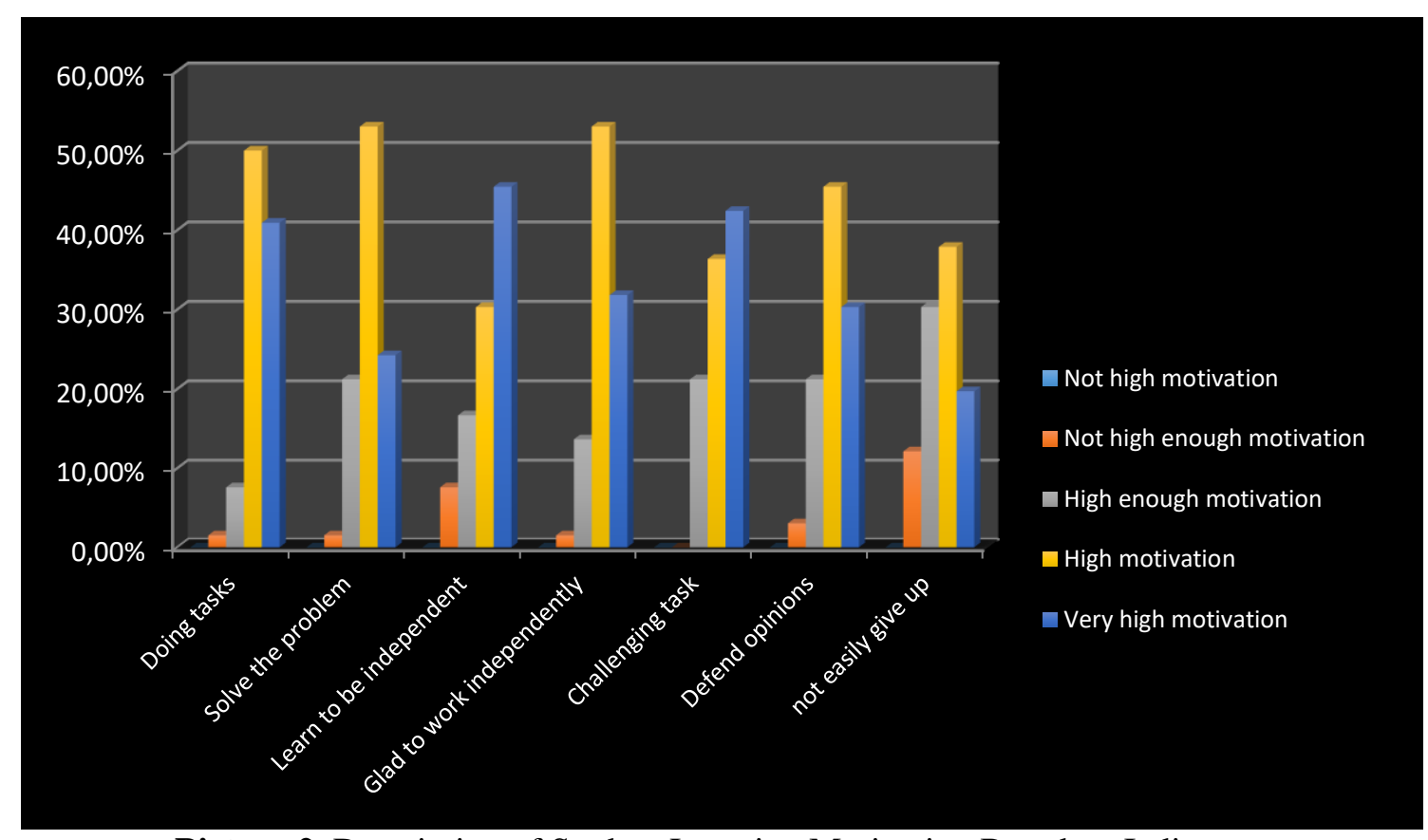

Picture 2. Description of Student Learning Motivation Based on Indicators

From the diagram, it can be concluded that in terms of doing tasks $40.91 \%$ of respondents have very high motivation, $50.00 \%$ of respondents have high motivation, $7.58 \%$ of respondents have not high enough motivation, and $1.52 \%$ of respondents have not high enough motivation. In solve the problem, $24.24 \%$ of respondents said that they were very high motivation, $53.03 \%$ said that they had high motivation, $21.21 \%$ of respondents said they had high enough motivation, and $1.52 \%$ of respondents said they had not high enough motivation. Learn to be independent indicators, $45.45 \%$ of respondents have very high motivation, $30.30 \%$ of respondents say they have high motivation, $16.67 \%$ of respondents say they have high enough motivation, and $7.58 \%$ of respondents have not high enough motivation For indicators of glad to work independently, $31.81 \%$ of respondents said that they had very high motivation, $53.03 \%$ of respondents said they had high motivation, $13.64 \%$ of respondents had high enough motivation, and $1,52 \%$ of respondents had not high enough motivation. For challenging tasks, $42.42 \%$ of respondents said they had very high motivation, $36.36 \%$ of respondents had high motivation, and $21.21 \%$ of respondents had high enough motivation. For indicators to defend opinions, $30.30 \%$ of respondents have very high motivation, $45.45 \%$ of respondents have high motivation, $21.21 \%$ of respondents have high enough motivation and $3.03 \%$ of respondents have not high enough motivation. Whereas for indicators not easily to give up, $19.70 \%$ of respondents have very high motivation, $37.88 \%$ of respondents have high motivation, $30.30 \%$ of respondents have high enough motivation, and $12.12 \%$ of respondents have not high enough motivation. 


\section{4| Jurnal Administrare: Jurnal Pemikiran Ilmiah dan Pendidikan Administrasi Perkantoran}

Volume 6 No. 1 January-June 2019. Pages 79-88

\section{The influence of ALS program on students learning motivation}

The data analysis technique used to determine the implementation of ALS on students learning motivation at Hangtuah City Tarakan High School is inferential statistical analysis. Correlation analysis aims to measure the relationship of ALS to students learning motivation at Hangtuah High School, Tarakan City. For more details, see the Table 3:

Table 3.

Correlation Analysis

\begin{tabular}{llc|c}
\hline & & $\begin{array}{c}\text { ALS } \\
\text { Implemantation }\end{array}$ & $\begin{array}{c}\text { Students Learning } \\
\text { Motivation }\end{array}$ \\
\hline ALS Implemantation & Pearson Correlation & 1 & $.724^{* *}$ \\
& Sig. (2-tailed) & & .000 \\
Students Learning Motivation & $\mathrm{N}$ & 66 & 1 \\
& Pearson Correlation & $.724^{* *}$ & \\
& & & \\
& Sig. (2-tailed) & .000 & 66 \\
\hline
\end{tabular}

Source: Results of 2018 Research Analysis

The correlation table displays the Pearson Correlation value to find out the magnitude of the relationship between variables. The Pearson Correlation value is 0.724 , this value if interpreted according to Sugiyono (2010: 257), it can be seen that the relationship between the Implementation of ALS towards students learning motivation at Hangtuah High School, Tarakan City is in the strong category, because it has strong relationships so it can proceed to find out the influence of the implementation of ASL program on student learning in the Hakanaguah High School in Tarakan City.

Regressions analysis was used to measure the influence between the implementation of ALS program on students learning motivation at Hangtuah City Tarakan High School. To find out the influence of the implementation of ALS program on student motivation in Tarakan City can be seen in Table 4:

\section{Table 4.}

The Influence ALS on Student Motivation

\begin{tabular}{lcccr}
\hline \multicolumn{5}{c}{ Model Summary $^{\mathbf{b}}$} \\
\hline Model & $\mathrm{R}$ & R Square & Adjusted R Square $^{2}$ & Std. Error of the Estimate \\
\hline 1 & $.724^{\mathrm{a}}$ & .525 & .517 & 3.29972 \\
\hline Source: Results of 2018 Research Analysis
\end{tabular}

From the table it is known that the value of R Square is 0.525 meaning that the Assignment of Lecturers in School (ALS) has an influence of $52.5 \%$ on student learning motivation in the city of Tarakan. Next is to determine the level of significance or linearity of the regression. The 
criteria can be determined based on the $\mathrm{F}$ test. The easiest way to determine significance is when the significance value of SPSS data is smaller than 0.05, then the regression model is linear, and vice versa. To find out the significance value can be seen in Table 5:

Table 5.

Regressions Analysis

\begin{tabular}{|c|c|c|c|c|c|c|}
\hline \multicolumn{7}{|c|}{ ANOVA $^{a}$} \\
\hline Model & & $\begin{array}{l}\text { Sum of } \\
\text { Squares }\end{array}$ & $\mathrm{df}$ & Mean Square & $\mathrm{F}$ & Sig. \\
\hline \multirow[t]{3}{*}{1} & Regression & 768.687 & 1 & 768.687 & 70.598 & $.000^{\mathrm{b}}$ \\
\hline & Residual & 696.843 & 64 & 10.888 & & \\
\hline & Total & 1465.530 & 65 & & & \\
\hline
\end{tabular}

Source: Results of 2018 Research Analysis

From the ANOVA or F Test, the $\mathrm{F}$ value is 14,365 , which means $\mathrm{H}_{\mathrm{a}} \neq 0$, So, $\mathrm{H}_{0}$ is rejected with a probability of 0,000 , because the probability is much smaller than 0.05 , then the regression model is linear meaning that it can be used to predict the Assignment of Lecturers at School (ALS) influences students learning motivation in Hangtuah City Tarakan High School.

\section{Discussion}

\section{Description of the Implementation of the Assignment of Lecturers at School Program (ALS) at Tarakan City.}

The main element of teacher education is lecturers. Besides having to have superior competencies, Lembaga Pendidikan Tenaga Kependidikan (LPTK) lecturers must also be a model for prospective teacher students. Therefore, lecturers must be able to provide good examples for prospective teacher students, in carrying out their professional duties, including how to carry out classroom learning because teaching is a difficult and complicated task (Harden \& Crosby, 2000; Johan , 2015; Tschannen-Moran \& Hoy, 2001). The application of the Assignment of Lecturers at School Program (ALS) is in good category if it is viewed from the learning climate the better, the learning device becomes more qualified, and the learning achievement increases. Of the three indicators, the learning climate objectives have the highest average with a very achievable category, meaning that the lecturers assigned to the school not only carry out teaching materials, but also provide positive reinforcement, encourage discovery by students, such as question and answer, discussion and experiment. Based on the results of observations, in structuring the learning climate the techniques used are synergistic and in accordance with the uniqueness and needs of students. From the results of data processing, the average quality learning tools are in the category achieved, the delivery of learning objectives delivered by lecturers at the beginning of learning makes students know what things they are learning, so learning becomes more focused besides the lecturers also use learning media that were never used by their previous teachers. The results of data processing on increasing student achievement are also in the category achieved, meaning that the Assignment of Lectrurers at School (ALS) is able to make student learning outcomes increase. 
86 | Jurnal Administrare: Jurnal Pemikiran Ilmiah dan Pendidikan Administrasi Perkantoran

Volume 6 No. 1 January-June 2019. Pages 79-88

\section{Description of The Student Learning Motivation at Tarakan City}

Individual behavior does not stand alone, there are always things that, push it and aim at a goal that you want to achieve. Motivation is divided into 2, namely intrinsic motivation and extrinsic motivation (Daskalovska, Gudeva, \& Ivanovska, 2012; Deci, Koestner, \& Ryan, 2001; DePasque \& Tricomi, 2015; Lin-Siegler, Dweck, \& Cohen, 2016; Pintrich , 2003; Su \& Cheng, 2015). Extrinsic motivation is the development of psychological or spiritual needs. Good teachers apply positive methods to motivate students so they are eager to learn and feel valued, willing to learn and follow the rules set at school.

Based on the results of the study, students learning motivation is in a high category if judged by doing tasks, solve the problem, learn to be independent, glad to work independently, challenging task, defend opinions and not easily to give up. Based on the results of data processing, 5 of the 7 indicators are in the high category while the other 2 are solve the problem and not easily to give up in the medium category, this is because there are some students who, if given challenging assignments, choose to delay working on assignments and choose to work on assignments from other teachers that are considered easy. As for indicators, not easily to give up in the medium category, based on observations, if lecturers apply discussion methods in class, at first they are active in discussing, but if there are differences of opinion between groups, there are some students who do not express their opinions again because they were afraid the opinion he had expressed was wrong.

\section{The Infleunce of Implementation Assignment of Lecturers at Achool (ALS) Program to Student Learniing Motivation in Tarakan City}

The results showed that there was a strong influence on the implementation of the Assignment of Lecturers in School Program (ALS) on the students learning motivation in Tarakan city, indicating that the better the implementation Assignment of Lecturers in School Program the higher the students learning motivation. ALS is an activity that has a positive impact on schools, especially students because of learning innovations conducted by lecturers. Doing the same thing continuously can lead to boredom and decrease the spirit of learning, students who are bored tend to disrupt the learning process, learning innovation makes students stay concentrated and motivated. In addition to learning innovations, lecturers also carry out activities that involve students, with the aim that they can share knowledge, ideas, and ways of completing individual tasks, by doing so students show interest and motivation to learn (Hawk \& Shah, 2007; Marrero, Woodruff, Schuster, \& Riccio, 2010; Roulston, 2010)

\section{CONCLUSION}

The description of the implementation of lecturer assignments in schools in a good category, while students learning motivation in the high category, and there a positive and significant influence between the implementation Assignment of Lecturers at School (ALS) program in learning motivation in Tarakan, which was $52.5 \%$ 


\section{REFERENCES}

Borko, H. (2004). Professional Development and Teacher Learning: Mapping the Terrain. Educational Researcher. https://doi.org/10.3102/0013189X033008003

Darling-Hammond, L., Hyler, M. E., \& \& Gardner, M. (2017). Effective teacher professional development. Learning Policy Institute. https://doi.org/10.1016/j.fusengdes.2007.07.052

Daskalovska, N., Gudeva, L. K., \& Ivanovska, B. (2012). Learner Motivation and Interest. Procedia - Social and Behavioral Sciences. https://doi.org/10.1016/j.sbspro.2012.05.272

Deci, E. L., Koestner, R., \& Ryan, R. M. (2001). Extrinsic Rewards and Intrinsic Motivation in Education: Reconsidered Once Again. Review of Educational Research. https://doi.org/10.3102/00346543071001001

DePasque, S., \& Tricomi, E. (2015). Effects of intrinsic motivation on feedback processing during learning. NeuroImage. https://doi.org/10.1016/j.neuroimage.2015.06.046

Direktorat Pembelajaran. (2018). Panduan program hibah Penugasan Dosen di Sekolah $(P D S)$.

Emmer, E. T., \& Stough, L. M. (2001). Classroom management: A critical part of educational psychology, with implications for teacher education. Educational Psychologist. https://doi.org/10.1207/S15326985EP3602_5

Djamarah, Syaiful, Bahri. 2010. Strategi Belajar Mengajar. Jakarta: Rineka Cipta.

Ghozali, Imam. 2011. Aplikasi Analisis Multivariete dengan Program IBM SPSS 19 Edisi 5. Semarang. Badan Penerbit Universitas Diponegoro.

Harden, R. M., \& Crosby, J. R. (2000). The Good Teacher is More Than A Lecturer. Medical Teacher. https://doi.org/10.1080/014215900409429

Hawk, T. F., \& Shah, A. J. (2007). Using Learning Style Instruments to Enhance Student Learning. Decision Sciences Journal of Innovative Education. https://doi.org/10.1111/j.1540-4609.2007.00125.x

Johan, K. (2015). Perception of Students Towards Lecturers Teaching Engineering Courses with Industry Experience: A Case Study in Malaysia Technical University. Procedia - Social and Behavioral Sciences. https://doi.org/10.1016/j.sbspro.2015.06.372

Koca, F., \& Ph, D. (2016). Motivation to Learn and Teacher - Student Relationship. Journal of International Education and Leadership, 6(2), 1-20.

Lin-Siegler, X., Dweck, C. S., \& Cohen, G. L. (2016). Introduction: Instructional interventions that motivate classroom learning. Journal of Educational Psychology. https://doi.org/10.1037/edu0000124

Lumsden, L. S. ., Learn, T., \& Digest, E. (1994). Student Motivation To Learn. ERIC Digests. https://doi.org/10.1503/cmaj.160179

Marrero, M. E., Woodruff, K. A., Schuster, G. S., \& Riccio, J. F. (2010). Innovative Teacher Professional Development. International Review of Research in Open and 
88 | Jurnal Administrare: Jurnal Pemikiran Ilmiah dan Pendidikan Administrasi Perkantoran Volume 6 No. 1 January-June 2019. Pages 79-88

Distance Learning. https://doi.org/10.3102/0013189X033008003

Nurwardani. 2018. Panduan Program Hibah penugasan Dosen di Sekolah (PDS). Jakarta. Direktorat Jenderal Pembelajaran dan Kemahasiswaan Kemenristekdikti.

Peacock, M. (2003). Motivational Strategies in the Language Classroom. English for Specific Purposes. https://doi.org/10.1016/S0889-4906(02)00009-1

Pintrich, P. R. (2003). Motivation and Classroom Learning. In Handbook of Psychology. https://doi.org/10.1002/0471264385.wei0706

Riduwan. 2009. Metode dan Teknik Menyusun Proposal Penelitian. Bandung: Alfabeta.

Roulston, K. (2010). "There is no end to learning": Lifelong education and the joyful learner. International Journal of Music Education. https://doi.org/10.1177/0255761410381822

Sardiman. 2012. Interaksi \& Motivasi Belajar Mengajar. Jakarta: Rajawali Pers

Seifert, T. L. (2004). Understanding student motivation. Educational Research. https://doi.org/10.1080/0013188042000222421

Su, C. H., \& Cheng, C. H. (2015). A mobile gamification learning system for improving the learning motivation and achievements. Journal of Computer Assisted Learning. https://doi.org/10.1111/jcal.12088

Sugiyono. 2010. Metode Penelitian Pendidikan Pendekatan Kuantitatif, Kualitatif dan $R \& D$. Bandung: Alfabeta.

Thoonen, E. E. J., Sleegers, P. J. C., Peetsma, T. T. D., \& Oort, F. J. (2011). Can teachers motivate students to learn? Educational Studies. https://doi.org/10.1080/03055698.2010.507008

Timperley, H., Wilson, A., Barrar, H., \& Fung, I. (2008). Teacher professional learning and development. The International Academy of Education. https://doi.org/10.1002/hrm

Tschannen-Moran, M., \& Hoy, A. W. (2001). Teacher efficacy: Capturing an elusive construct. Teaching and Teacher Education. https://doi.org/10.1016/S0742051X(01)00036-1

Wang, J., Lin, E., Spalding, E., Odell, S. J., \& Klecka, C. L. (2011). Understanding Teacher Education in an Era of Globalization. Journal of Teacher Education. https://doi.org/10.1177/0022487110394334 